
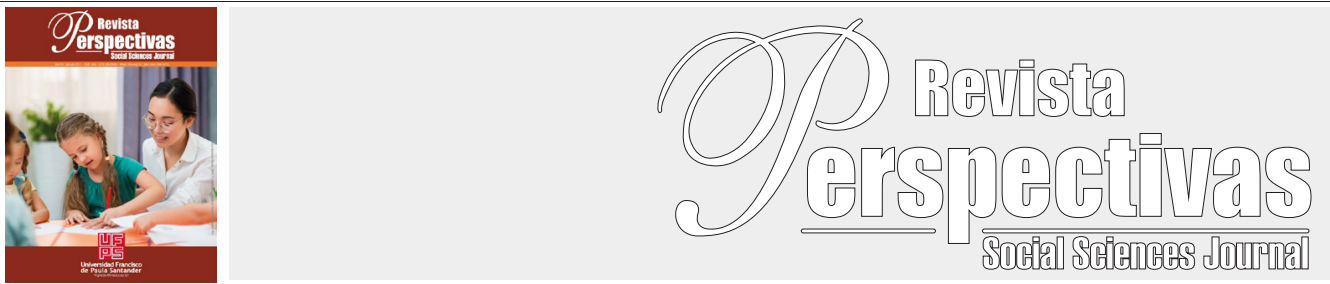

Artículo Original

https://doi.org/10.22463/25909215.2922

\title{
The human rights-based approach in public policies: from institutionality to citizenship.
}

El enfoque basado en derechos humanos en las políticas públicas: de la institucionalidad a la ciudadanía.

Jefferson Alexander Rodríguez-Gómez ${ }^{1}$

${ }^{l}$ Administrador Público,gp_ja_rodriguez@fesc.edu.co, ORCID:0000-0001-5409-3466, Fundación de Estudios Superiores FESC, Cúcuta, Colombia

How to cite: J.A. Rodríguez-Gómez, "The human rights-based approach in public policies: from institutionality to citizenship.". Perspectivas, vol. 6, no. 1, pp. 34-45, 2021.

Recibido:August 25, 2020; Aprobado: November 18, 2020.

\begin{tabular}{ll}
\hline ABSTRACT \\
\hline Keywords: & $\begin{array}{l}\text { This article is a product of the research project "Public policies, citizenship and the human rights approach } \\
\text { in the Norte de Santander Department" carried out as a public management project - social extension of the } \\
\text { Comfanorte Higher Studies Foundation - FESC in the Public Management Specialization Program. The aim }\end{array}$ \\
Citizenship, & was to describe conceptual and methodological elements that would allow the proposal of foundations for \\
Human Rights-Based & the formulation of public policies with a long-term vision and a human rights-based approach for the Norte \\
Approach and Public & de Santander Department, with a scope that includes the identification of the problem, the definition of the \\
Policy & population, the diagnosis and the action plan. To this end, from the qualitative approach, theoretical foundations \\
& were adopted to support the proposal under the protection of interdisciplinary information sources through \\
& interviews with public policy experts in the region. Finally, the importance of differential approaches in the \\
& formulation of public policy was recognized, since their specificity guarantees in a differential manner the \\
& satisfaction of the rights of the different population groups, as well as the transverse and incidental participation \\
of the citizenry as necessary in all phases of the formulation, which is fundamental to the success of public \\
policy.
\end{tabular}

\section{RESUMEN}

Palabras clave:

Ciudadanía, Enfoque Basado en Derechos Humanos y Políticas Públicas.
Este artículo es producto del proyecto de investigación "Políticas públicas, ciudadanía y el enfoque de Derechos Humanos en el Departamento Norte de Santander" realizado como proyecto de gestión pública - extensión social de la Fundación de Estudios Superiores Comfanorte FESC en el programa Especialización en Gestión Pública. Las pretensiones giraron en torno a describir elementos conceptuales y metodológicos que permitan proponer fundamentos para la formulación de políticas públicas con visión a largo plazo con enfoque basado en derechos humanos para el Departamento Norte de Santander con alcance en identificación de la problemática, definición de la población, diagnóstico y plan de acción. Para ello, desde el enfoque cualitativo se acogieron cimientos teóricos que fundamentan la propuesta al amparo de fuentes de información interdisciplinares a través de entrevistas a expertos en políticas públicas de la Región, logrando finalmente reconocer la importancia de los enfoques diferenciales en la elaboración de políticas públicas, toda vez que, por su especificidad garantiza de manera diferencial la satisfacción de los derechos a los distintos grupos poblacionales, así como, la participación trasversal e incidente de la ciudadanía como necesaria en todas las fases de la formulación, la cual es fundamental para lograr el éxito de la política pública.

\section{Introduction}

This article aims to describe strategic elements identified as fundamental when formulating public policies based on the characteristics of the human rights-based approach (HRBA), including the participation of citizens in all phases of the formulation, taking into account that in Norte de Santander no clear elements were found for the formulation of public policies under this approach, nor documents that methodologically guide both institutions and citizens in the construction of policies to solve the different social problems within the framework of human rights.

Successful institutional experiences were found in some local governments in Colombia, as for example in the capital District of Bogotá, where 
the respective Planning Office created guides that offer methodological and conceptual guidelines for the formulation of public policies, which have been fruitful for the construction of public policies, all of which is evidenced by the high number of policies designed with a differential approach addressed from the human rights approach as a comprehensive response to the needs, which, has allowed them to "strengthen the capacities of the entities of the Capital District in the structuring of public policies as long-term planning instruments" (Alcaldía Mayor de Bogota D. C, 2019).

Although "there is no standard methodology to analyze public policies" (Muller, 2012), some fundamental elements were identified for both public policy makers and citizens, in which they will be described in detail in this article with the purpose of proposing some methodological aspects to formulate public policies relevant to the Department, taking into account the human rights-based approach.

To illustrate this consideration, Muller (2012) offers to define some elements for a research strategy on public policies based on the following questions: "how are public policies born and transformed?" "how do public organizations function and how are public policies implemented? The above, in order to distinguish the actors, processes, strategies and methods to be considered in the object of the research.

In this sense, it is important to know first what public policy is, according to Roth (2002) who states that it is:

A set made up of one or several collective objectives considered necessary or desirable, of means and actions that are addressed, at least partially, by a government institution or organization with the purpose of guiding the behavior of individual or collective actors to modify a situation perceived as unsatisfactory or problematic (p.27).
For his part, Velasquez (2009) descriptively defines public policy as an integrated process of decisions, actions, inactions, agreements and instruments, carriedoutbyauthorities with theeventual participation of individuals, and aimed at solving or preventing a situation defined as problematic. The above are elements that can distinguish a public policy from other government actions, and are useful for identifying key characteristics for the construction of a methodological framework for its formulation (p.156).

The human rights-based approach, according to the Office of the High Commissioner for Human Rights (2006), is a conceptual framework for the human development process that from the normative point of view is based on international human rights standards and from the operational point of view is oriented to the promotion and protection of human rights.

In this sense, the importance of building public policies with a human rights-based approach is recognized, taking into account the observance of human rights, in light of the fundamental rights recognized in the Political Constitution, which are promoted by norms such as, for example, the Statutory Law on Citizen Participation and the Decree creating the National Human Rights System.

Within the framework of this approach, the Mayor's Office of Bogota (2017) states that it is understood as:

The way of directing attention or interest towards a matter to achieve a greater understanding of the realities, situations and social needs, which allows providing relevant responses by the State, in turn it is found that, the human rights approach comprehensively and relationally comprises the gender approach, the population approach, the differential approach, the territorial approach and the environmental approach (p.11).

Given the above conditions, it is inferred that the formulation of public policies based on a human 
rights approach is a process of social construction with a long-term vision, oriented in a planned manner to the achievement of priority objectives, established in a concerted and participatory manner between the government and the key social actors involved such as unions, citizens, academia, civil society, church and others, in which the different approaches (human, gender, differential, population and territorial) can be taken into account as a strategic tool of public management oriented to the achievement of results. According to Torres-Melo and Santander (2013) "they are a reflection of the ideals and desires of society, they express the objectives of collective welfare and allow understanding where development is to be oriented and how to do it, showing what public intervention is intended to achieve and how responsibilities and resources are distributed among social actors" (Torres-Melo and Santander, 2013).

\section{Materials and Methods}

The research was undertaken from a qualitative approach under a descriptive method, which according to Tamayo and Tamayo (1999) "aims to systematically describe the characteristics of the area of interest". Under the pretensions of the research to recognize key elements to be taken into account for a methodology at the time of formulating policies, documentary tracking of primary and secondary sources was carried out; on this conceptual basis, an interview was designed as a collection technique welcoming conceptual interdisciplinarity, understood as "the relationship established between disciplines, incorporating the results of the various disciplines, taking it from the various conceptual schemes of analysis, subjecting them to comparison and finally, integrating them" (Tamayo and Tamayo, 1999). In this sense, the participating subjects are professional experts who were selected under the following criteria: technical knowledge of the subject, professional expertise and territorial recognition.

Regarding the data collection techniques, the interview was selected, according to Báez and Pérez de Tudela (2012) "it is an intensive technique used to deepen in those theoretical and global aspects that constitute the specialized discourse (ideological and professional) on a topic and the foundations on which it is based". In accordance with this, for Hernández, Fernández and Baptista (2014), "the qualitative interview is defined as a meeting to converse and exchange information between one person (the interviewer) and another person (the interviewee), in which through questions and answers, communication and the joint construction of meanings regarding a topic are achieved".

With regard to the processing of the interviews, alphabetical codes were used for each unit of analysis and participating subject.

In view of the above, three theoretical categories were defined for the research, which are: Public Policy, Citizenship and Human Rights Based Approach, for each one a deductive category was defined, being respectively the following: formulation, participation and relevance; from the previous ones emerged as unit of analysis the active subjects, structural and experiential elements against regional background for the formulation, while, for the participation, the analysis from the importance and mechanisms. Finally, the relevance of the HRBA was analyzed from the units of incidence and observance, as well as the considerations of the interviewees in relation to public policies.

For the analysis of the information, alphabetical codes were generated that made it possible to process the responses of the participating subjects under the following defined criteria: 
Table I.Unit of analysis codes

\begin{tabular}{|c|c|c|c|}
\hline Categoría teórica & Categoría deductiva & Unidad de análisis & $\begin{array}{l}\text { Código unidad de } \\
\text { análisis }\end{array}$ \\
\hline \multirow{3}{*}{ Política Pública } & \multirow{3}{*}{ Formulación } & Sujetos activos & SA \\
\hline & & $\begin{array}{l}\text { Elementos } \\
\text { estructurales }\end{array}$ & $\mathrm{EE}$ \\
\hline & & $\begin{array}{l}\text { Antecedentes } \\
\text { regionales }\end{array}$ & AR \\
\hline \multirow{2}{*}{ Ciudadanía } & \multirow{2}{*}{ Participación } & Importancia & I \\
\hline & & Mecanismos & M \\
\hline \multirow{2}{*}{ EFBH } & \multirow{2}{*}{ Relevancia } & $\begin{array}{l}\text { Incidencia y } \\
\text { observancia }\end{array}$ & IO \\
\hline & & $\begin{array}{c}\text { Consideraciones } \\
\text { frente a Política } \\
\text { Pública }\end{array}$ & CPP \\
\hline
\end{tabular}

Source: own elaboration

The table above details the codes defined for each unit of analysis, according to deductive and theoretical categories, with which the information collected was processed.

Roman numeral codes were generated for the responses of the participating subjects, which made it possible to recognize the recurrences from each unit of analysis and facilitated the processing.

\section{Results and Conclusion}

Formulation of Public Policies from a Human Rights Based Approach.

Once the interview process was completed, the information was processed for analysis according to the aforementioned theoretical and deductive categories, by means of which the following results were obtained:

Regarding the formulation of public policies, the interviewees were recurrent in stating that the participation of citizens as active intervening subjects from the genesis of public policies is indispensable, but also, of the institutionality represented in the government of the day and its will, as well as of the interest groups; on the other hand, it was considered relevant to identify who may be the beneficiaries, those affected, and interested in financing the Public Policy.

Regarding the structural elements in such formulation, the participants agreed in considering that technical research is key to generate the situational and contextual diagnosis, the first from the differential population approach and the second from the territorial approach, fundamental for the construction of the baseline of the public policy; as well as to identify the problem, those involved and the selection of alternatives or solutions based on the participation of the citizens; also for the definition of an Action Plan with goals, objectives and resources as a result of a planning process in which the best possible alternative that guarantees its feasibility is contemplated, fundamental pieces for decision making, given either under the agreement, consensus or negotiation of the different actors, under a process of technical-political articulation. All this, considered as a strategic planning process based on the differentiating elements of the human rights approach. 
Finally, for the category surveyed from the regional background, the interviewees stated that in Norte de Santander public policies have not been formulated in effect, since the aforementioned elements are not fully implemented, in this sense, they consider that the CONPES documents are not Public Policy, but policy guidelines, given in a context of homogenization of the national order, subordination of the territorial order and little autonomy of the departmental entity. They are constructed from the national level with no knowledge of the territorial reality, its characteristics and differences, in which the different actors are not taken into account, but only some representatives, who do not take into account the interests of the entire social base, so that there is no real process of consensus or consensus; that is to say, the citizens have little influence in their elaboration, because their participation is mere formality.

Table II. Systematization of results Public Policy category

\begin{tabular}{|c|c|c|c|c|}
\hline \multirow{2}{*}{\multicolumn{2}{|c|}{$\begin{array}{l}\text { Categoría Teórica } \\
\text { Categoría Deductiva }\end{array}$}} & \multicolumn{3}{|c|}{ Política Pública } \\
\hline & & & Formulación & \\
\hline \multirow{2}{*}{\multicolumn{2}{|c|}{ Unidad de Análisis }} & $\underline{1}$ & $\underline{2}$ & $\underline{3}$ \\
\hline & & $\begin{array}{l}\text { Sujetos } \\
\text { Activos }\end{array}$ & $\begin{array}{c}\text { Elementos } \\
\text { Estructurales }\end{array}$ & $\begin{array}{c}\text { Antecedentes } \\
\text { Regionales }\end{array}$ \\
\hline \multicolumn{2}{|c|}{ Código } & SA & $\mathrm{EE}$ & $\mathrm{AR}$ \\
\hline \multirow{3}{*}{$\begin{array}{l}\text { Sujeto } \\
\text { participante }\end{array}$} & FT & FT/I-II - III & FT/I-II - III-IV-V-VI & FT/I-II - III-IV \\
\hline & HD & HD/I - II- III & HD/I-II-III-IV-V-VI & HD/I-II - III-IV-V \\
\hline & JB & $\begin{array}{c}\text { JB/I - II - III- } \\
\text { IV-V-VI }\end{array}$ & JB/I-II-III-IV-V-VI & JB/I-II - III-IV \\
\hline
\end{tabular}

Source: own elaboration.

The table above details the processing carried out for the analysis based on the recurrences of the participating subjects from the units of Active Subjects, Structural Elements and Regional Antecedents in relation to the formulation as a deductive category of the theoretical category Public Policy.

\section{From Institutionality to Citizenship}

On the other hand, with regard to citizenship, the participants were asked about the importance of citizens in the formulation of public policies, in such a way that the experts agreed that the participation of citizens in the formulation phase is fundamental, because it is the citizens themselves who detect the problem, first by the perception they have of reality and second, by the knowledge of its cause, since it is the subjectivation of the problem based on their interests and expectations. However, it was found that they agree that this requires technical discernment and the capacity of the formulators to objectify it, without disregarding, of course, the manifest will of the citizens. In other words, the formulation with citizen participation, technically guided by the formulators.

In any case, they agree that citizen participation is important in all phases for the design of public policies, as Ochoa cited by Gutiérrez, Restrepo, and Zapata (2017), Consequently, participation is 
important in all stages of the Public Policy, but especially from the formulation, because it is there where citizens participate from their own knowledge, identifying and deciding which problems should be prioritized and how they can be solved, guaranteed that, it is given a human rights approach.

Likewise, they were consulted about the mechanisms that can be promoted from the institutional framework for them to participate in the identification of the needs to be prioritized and to influence in the decision making process of the issues that affect them, for which they expressed the importance of promoting an active citizenship, in which the citizen is the center of everything in public policies, even from the formulation, as a constant for the decision making process and social control.

Likewise, on the part of the institutional framework, it is necessary to strengthen training spaces in political culture, history, development of abilities, skills and critical capacities and mastery of real processes, and to promote decisive spaces such as: community councils, participatory budget, local instances, differential councils, thematic forums and technical tables of participation, where there is listening and social dialogue.

According to those interviewed, the above strengthens citizens' capacities to demand and participate in the definition of clear public agendas with problems to be prioritized and an empowered citizenry for the negotiation or agreement of pacts and commitments made by the institutions.

\begin{tabular}{lccc}
\multicolumn{3}{c}{ Table III. Systematization of results Citizenship category } \\
Categoría Teórica & \multicolumn{3}{c}{ Ciudadanía } \\
Categoría Deductiva & \multicolumn{2}{c}{ Participación } \\
\hline \multicolumn{1}{c}{ Código } & & Importancia & $\underline{5}$ \\
Unidad de Análisis & I & Mecanismos \\
& FT & FT/ I - II & MP $/$ I - II \\
Sujeto & HD & HD/I-II & HD/I-II \\
participante & & JB/I-II & HD/I-II-III \\
& JB & &
\end{tabular}

The table above details the processing carried out for the analysis based on the recurrences of the participating subjects from the units of importance and mechanisms in relation to participation as a deductive category of the theoretical category citizenship.

\section{The differentiating elements of the human rights-based approach, qualities for citizenship.}

Finally, the experts were asked about the importance of formulating public policies with a human rights-based approach, according to the observance it deserves, and how it can facilitate or not its strategic construction. In this sense, the 
interviewees considered that Public Policies based on the human rights approach are the strategic satisfaction of human needs, which allows the materialization of unsatisfied rights in a territory to achieve development, since it develops the Social State of Law guaranteeing the citizen the protection of human rights and that its observance is transcendental as a starting point to objectify the problem and establish which is the human right that is not being satisfied.

Consequently, the interviewees considered that in the context of Norte de Santander, Public Policies based on human rights approaches are very necessary for the Department, due in part, not only to the possible human rights violations that occur in the territory, but also due to the lack of observance of these rights.

Similarly, it was found that for the participants it is important to recognize the qualities of the HRBA when formulating public policies to guarantee with equity and equality the satisfaction of human rights for the development of all citizens, in a differential manner, but without discrimination, within the framework of human dignity, reason and justice.

One of these qualities, which was identified is the specificity that public policies need to mitigate a particular problem, taking into account human rights-based approaches, such as population, differential, gender and territorial, through which the conditions of the territory and the population to be intervened can be characterized, with the purpose of guaranteeing the success of the public policy from its delimitation.

On the other hand, it was found that for the JB, the EBDH gives the possibility to analyze and confront inequalities, since it corrects the different discriminatory situations and the inequitable form of power and wealth that hinder the development of the different communities. In addition, it improves the capacities of the fundamental actors of the process, recognizing public servants as duty-bearers and citizens as holders of enforceable rights that they can claim.

He also added that it is important because it fosters the political advocacy processes of citizens to achieve the realization of rights in accordance with the needs and demands of the various population groups.

Finally, it was identified that the interviewees defined some elements that can be fundamental as guidelines for the formation of public policies with a human rights-based approach, for example, for FT it is important to consider necessary as a first component the knowledge of the territorial context or situational diagnosis of human rights in Norte de Santander and the territorial development trends around these rights, i.e., previous research that has been done in the territory to define the baselines.

For its part, HD considered that these differentiating elements of the EBDH endow public policies in their formulation, given that it is a clear route to guarantee human rights with specificity, facilitating the actors' understanding of the norms. From the exercise of citizenship in decision-making as the central axis of the HRBA, it is promoting the development of the fundamental rights recognized in the Colombian Magna Carta.

Similarly, JB recognized that citizenship is fundamental for the definition of public problems, proposals, solution alternatives and decision making, but that, under the protection of human rights, the minimum conditions of accessibility, accessibility, adaptability and acceptability of citizens must be guaranteed, especially when talking about the formulation of public policies with a human rightsbased approach. 
Table IV. Systematization of results EBDH category

\section{Categoría Teórica \\ EBDH}

Categoría Deductiva Relevancia

\begin{tabular}{lccc}
\hline Unidad de Análisis & & $\underline{6 \text { y } 7}$ & $\underline{8}$ \\
& & $\begin{array}{c}\text { Incidencia y } \\
\text { observancia }\end{array}$ & $\begin{array}{c}\text { Consideraciones } \\
\text { frente a las PP }\end{array}$ \\
Código & IO & CPP \\
$\begin{array}{c}\text { Sujeto } \\
\text { participante }\end{array}$ & FT & FT/ I - II-IV-X & FT/ I - II \\
& & HD/-III-IV-V-VI-X & HD/I-II-III \\
& JB & HD/I-V-VI-VII-VIII- & HD/II-III \\
& & IX-X &
\end{tabular}

The table above details the processing carried out for the analysis based on the recurrences of the participating subjects from the units of incidence, observance and considerations regarding the relevance as a deductive category of the theoretical category HRBA.

As a result of all this theoretical and methodological deployment, it was found that for the formulation of Public Policies with HRBA it is fundamental the transversal participation of citizens in all phases from the definition of the problem and the population with a differential approach, the elaboration of the diagnosis and the planning of actions, all of this under the technical guidance of the formulators in articulation with the institutional framework.

Finally, this article leaves the door open to other research aimed at identifying new significant future elements for the formulation of public policies, which can configure a methodology under the protection of human rights approaches, fundamental for defining and consolidating in the future a public management tool towards a more effective and efficient strategic planning to solve social problems, in any case, always with the recognition of citizenship as the central axis of the development of this process.

\section{Conclusions}

It can be deduced that for the formulation of public policies based on the human rights approach, the citizenry plays an important role in all its phases, from the identification of the problem, the definition of the population, the elaboration of the diagnosis and the construction of the action plan, in which, in coordination with the institutional framework, it manages to make a great contribution in each one of them, taking into account the recognition of their differentiating elements as qualities for citizenship, since they facilitate government intervention due to their specificity, the democratization of decisions and the guarantees of minimum conditions of participation, fundamental at the moment of 
formulating public policies for a certain population group within a particular territory.

In this sense, it is considered that one of the fundamental elements as a starting point for the formulation is the realization of the initial diagnosis, which can be situational and contextual, the former carried out from the point of view of the characteristics of the population based on the differential population approach, and the latter from the characteristics of the territory, based on the differential territorial approach, This is important for the success of the public policy in terms of its direct impact on the population that it really seeks to benefit, in which process the participation of citizens is important, technically guided by the formulators.

Finally, it is considered that the process of designing public policies with a human rights-based approach is a prospective tool for effective and efficient planning that can serve to strategically solve public problems or satisfy the rights of a population located in a territory, in which it is essential that citizens participate in order to achieve their own development.

\section{References}

Alcaldía Mayor de Bogotá D.C. (2017). Guía para formulación e implementación de políticas públicas del Distrito. Bogotá D.C: Arkimax Internacional Ltda. Retrieved 04 02, 2020 from https://bit.ly/3hu3Dv9

Alcaldía Mayor de Bogota D.C. (2019). Informe Balance Estratégico Sector de Planeación 2019 - 2019. Secretaria Distrital de Planeación, Bogota D.C. Retrieved 04 10, 2020 from https:// bit.ly/2Y2KtEQ

Asamblea Nacional Constituyente. (1991). Constitución Política de Colombia. (C. Constitucional, Ed.) Bogotá, Colombia. Retrieved 04 15, 2020 from https://bit.ly/2Y4zUBd
Baéz y Pérez de Tudela, J. (2012). Investigación Cualitativa (2da ed.). Madrid: ESIC.

Bernal Olarte, A. (2008). Buenas Prácticas Experiencias Locales en Políticas Públicas para las mujeres y la Equidad de Género. Bogotá.

Camara de Comercio de Cúcuta.(2019). PRODUCTO INTERNO BRUTO 2018 Pr. Cúcuta. Retrieved 04 10, 2020 from http://www.datacucuta.com/ images/PIB2018PR.pdf

Castillo Cubillos, M. (2017). El papel de la participación ciudadana en las políticas públicas, bajo el actual escenario de la gobernanza: reflexiones teóricas. Revista CS, 23, 157-180. doi:http://dx.doi.org/10.18046/recs.i23.2281

Clark, H. (2017, 03 21). Desarrollo humano significa que cada persona alcance todo su potencial. Retrieved 04 02, 2020 from Blog PNUD: Helen Clark

Congreso de Colombia. (24 de septiembre de 1996). Ley 319 de 1996. Bogotá D.C: Diario Oficial No. 42.884. Retrieved 05 20, 2020 from https://bit. 1y/37xQzA7

Congreso de la República. (01 de marzo de 2018). Ley Estatutaria 1885 de 2018. Bogotá D.C: Diario Oficial No. 50.522. Retrieved 05 30, 2020 from https://bit.ly/2zFIxsI

Congreso de la República. (18 de enero de 2011). Código de Procedimiento Administrativo y de lo Contencioso Administrativo. Ley 1437 de 2011. Bogota D.C: Diario Oficial No. 47.956. Retrieved 05 30, 2020 from https://bit.ly/2UN1jFX

Congreso de la República. (6 de julio de 2015). Ley Estatutaria 1757 de 2015. Bogotá: Diario Oficial No. 49.565. Retrieved 05 30, 2020 from https:// bit.ly/2YCBh9t

CONPES. (2013). CONPES 3739 ESTRATEGIA 
DE DESARROLLO INTEGRAL DE LA REGIÓN DEL CATATUMBO. BOGOTA. Retrieved 04 12, 2020 from https://corponor.gov.co/publica recursos/POBLACION_VULNERABLE/ Conpes_3739_de_2013.pdf

Consejería Presidencial para los Derechos Humanos. (2015). Estrategia Nacional para los Derechos Humanos 2014 - 2034. Colombia: Imprenta Nacional. Retrieved 05 03, 2020 from https://bit. ly/2UHVN7p

Consejo Nacional de Política Ecónómica y Social. (2014). CONPES 3805 PROSPERIDAD PARA LASFRONTERASDE COLOMBIA.Bogotá D.C., Colombia. Retrieved 04 10, 2020 from https:// colaboracion.dnp.gov.co/CDT/Desarrollo $\% 20$ Territorial/CONPES\%203805\%20DE\%20 2014\%20-\%20Prosperidad\%20para\%20las\%20 fronteras $\% 20 \mathrm{de} \% 20$ Colombia.pdf

Corte Constitucional de Colombia. (n.d.). SENTENCIA C-774 DE 2001. Retrieved 05 10, 2020 from https://bit.ly/2N261Lv

DANE. (2019). Pobreza Multidimensional por departamentos 2018. BOGOTÁ D.C. Retrieved 04 11, 2020 from https://www.dane.gov.co/files/ investigaciones/condiciones vida/pobreza/2018/ presentacion_pobreza_multidimensional_18_ departamento.pdf

DANE. (2019). Resultados Censo Nacional de Población y Vivienda 2018. Cucuta. Retrieved 04 15, 2020 from https://www.dane.gov.co/files/ censo2018/informacion-tecnica/presentacionesterritorio/190806-CNPV-presentacion-Norte-deSantander.pdf

DANE. (2020). Mercado laboral por departamentos 2019. Boletín Técnico, Bogota D.C. Retrieved 04 10, 2020 from https://www.dane.gov.co/ files/investigaciones/boletines/ech/ml_depto/ Boletin_dep_19.pdf
Departamento Adminsitrativo de la Presidencia de la República. (Mayo 26 de 2015). Decreto Reglamentario Único del Sector Presidencia de la República. Decreto 1081 de 2015. Bogotá. Retrieved 05 30, 2020 from https://bit. ly/2N52hsw

Función Pública. (2020). Manual de Estructura del Estado Colombiano. Retrieved 04 25, 2020 from https://bit.ly/2CenHBH

Gobernación Norte de Santander. (2019). Informe de Gestión con Énfasis en la Garantía de Derechos de la Infancia, Adolescencia y Juventud 2016 2019. Informe de gestion, Secretaria de Gobierno, Norte de Santander. Retrieved 04 22, 2020 from https://bit.ly/3e5RjiC

Guía para la formulación e implementación de políticas públicas del Distrito. (2017). Retrieved 01 10, 2020 from http://www.sdp. gov.co/sites/default/files/planeacion/guia para la_formulacion_de_politicas_publicas_del_ distrito_capital.pdf

Gutiérrez Ossa, J. A., Restrepo Avendaño, R. D., \& Zapata Hoyos, J. S. (2017). Formulación, implementación y evaluación de políticas públicas desde los enfoques, fines y funciones del Estado. CES Derecho, 8(2), 333-351. Retrieved 03 15, 2020 from https://bit.ly/2zzQ6B7

Hernández Sampieri, R., Fernández Collado, C., \& Baptista Lucio, M. (2014). Metodología de la Investigación (6ta ed.). México: McGRAWHILL.

Lahera, E. (2004). Política y Políticas Públicas. Santiago de Chile: Naciones Unidas. Retrieved 05 20, 2020 from https://bit.ly/3dcdNgI

Mejía Jimenez, J. (2012). Modelos de implementación de las políticas públicas de Colombia y su impacto en el bienestar social. Analeta Política, 2(3), 141-162. Retrieved 05 10, 2020 from https://bit. 
ly/3ftil3D

Ministerior de Interior. (26 de mayo de 2015). Decreto Único Reglamentario del Sector Administrativo del Interior. Decreto 1066 de 2015. Bogotá. Retrieved 05 20, 2020 from https://bit.ly/37vFwYo

Muller, P. (2012). Las Políticas Públicas (4 ed.). (U. E. Departamento de Públicaciones, Ed., J.-F. Jully, \& C. Salazar Vargas, Trans.) Bogotá D.C, Colombia: Universidad Externado de Colombia.

Naciones Unidas. (2015). Declaración Universal de Derechos Humanos. Retrieved 05 30, 2020 from https://bit.ly/37C6xJQ

Oficina del Alto Comisionado Para los Derechos Humanos. (2006). Preguntas frecuentes sobre el enfoque de derechos humanos en la cooperación para el desarrollo. Ginebra, Suiza. Retrieved 04 30, 2020 from https://bit.ly/2Bbx $7 \mathrm{gJ}$

Payeres Mendoza, D. (2019). Reseña ciudadanos del mundo: hacía una teoría de la ciudadanía Tercera Edición, 2009. Adela Cortina. Revista Internacional de Cooperación y Desarrollo, 6(1), 215-217.

Programa de las Naciones Unidas para el Desarrollo. (2019). Norte de Santander, retos y desafíos para el Desarrollo Sostenible. Cúcuta. Retrieved 04 15, 2020 from https://bit.ly/2zySWGq

Programa de Naciones Unidas Para el Desarrollo. (2020, 06 02). El PNUD en Colombia. Retrieved 10 06, 2020 from https://bit.ly/30JcbIr

Ramírez Saíz, J. (1999). Reseña de "Ciudadanos del mundo. Hacia una teoría de la ciudadanía" de Adela Cortina. Espiral, V(15), 235-245. Retrieved 05 10, 2020 from https://www.redalyc. org/articulo.oa? $\mathrm{id}=13851511$

Red de Observatorios de DDHH y DIH Norte de
Santander. (2017). Informe situacional del Derecho a la vida y la integreidad personal en Norte de Santander. Norte de Santander. Retrieved 04 15, 2020 from http://www. derechoshumanos.gov.co/Prensa/2017/ Documents/2-\%20An\%C3\%A 1 lisis \% 20 Situacional $\% 20$ DDHH $\% 20$ en $\% 20$ Norte $\% 20$ de\%20Santander.pdF

Roth Deubel, A.-N. (2002). Políticas Públicas. Formulación, Implementación y Evaluación. Bogotá: Ediciones Aurora. Retrieved 03 10, 2020 from https://bit.ly/30LNV8S

Subgrupo de Democracia y Derechos Humanos de la Cooperación Internacional en el Perú. (2013). Formulación de políticas públicas y proyectos de desarrollo. Guía para aplicar el EBDH. Lima: Biblioteca Nacional del Perú. Retrieved 04 01, 2020 from https://bit.ly/3e6v6AK

Tamayo y Tamayo, M. (1999). Serie Aprende a Investigar (3ra ed., Vol. 2). Bogotá D.C: ICFES.

Torres-Melo, J., \& Santander A, J. (2013). Introducción a las Políticas Públicas: Conceptos y Heramientas desde la relación entre Estado y Ciudadanía. (IEMP, Ed.) Bogotá: Imprenta Nacional de Colombia. Retrieved 05 01, 2020 from https://bit.ly/2C346Ea

Unión Interparlamentaria; Oficina del Alto Comisionado para los DDHH. (2016). Drechos Humanos. Ginebra, Suiza. Retrieved 05 10, 2020 from https://bit.ly/30M8sKc

Velásquez Gavilanes, R. (2009). Hacia una nueva definición de concepto "política pública". Desafios(20), 149-187. Retrieved 05 10, 2020 from https://bit.ly/2N04Ufx

Vicepresidencia de la Republica de Colombia. (2013). Guía conceptual y metodológica para el diseño y la formulación de la Política Pública "De la violencia a la sociedad de los derechos. Propuesta 
de Política Integral de Derechos Humanos 20142034. Bogotá: Grafik Publimpresos. Retrieved

03 10, 2020 from https://bit.ly/2N36oFA 